\title{
Life Table Parameters, Thermal-Requirements and Development Rate of Stethorus gilvifrons (Mulsant) Reared on Two-Spotted Spider Mite Tetranychus urticae (Koch) \\ Fatma M. Saleh \\ Plant Protection Research Institute, Agricultural Research Center, Ministry of Agriculture, Giza, Egypt
}

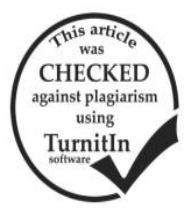

\begin{abstract}
Laboratory experiments were carried out in plant Protection Research Institute during 2016. The effect of temperatures under three different constant temperature $\left(15,25\right.$ and $\left.35^{\circ} \mathrm{C}\right)$ and rate of developmental time immature stages, growth index, developemantal rate, longevity, fecundity, and life table parameters of Stethorus gilvifrons (Mulsant), when reared on Tetranychus urticae (Koch) were studied. The relationship among developmental rate of each stage and tested temperatures was also investigated. There were significant ranges in total of developmental time immature stages of the predator (male and female) among the three tested temperatures when the predator was reared on T. urticae as preye. Mean while, developmental rate of $S$. gilvifrons male were higher at $35^{\circ} \mathrm{C}$ than 15 and $25^{\circ} \mathrm{C}$ when reared on this tetranychid mite. Adult male longevity was high significant shorter at 35 than 15 and $25^{\circ} \mathrm{C}$. There were significant differences in pre-oviposition period at the three temperatures. In addition, there were significant ranges among pre-oviposition, oviposition, post ovi-position and total longevity when the predator was reared at the three constant temperatures. Fecundity rate was significantly higher at $35^{\circ} \mathrm{C}$ than at $15^{\circ} \mathrm{C}$ and $25^{\circ} \mathrm{C}$ when fed on the T.urticae prey. Mean generation time (T) and the doubling time (DT) were higher at $15^{\circ} \mathrm{C}$ than at $25^{\circ} \mathrm{C}$ and $35^{\circ} \mathrm{C}$ when fed on the T.urticae individuals. The value of the gross reproductive rate (GRR), net reproduction rate $\left(R_{o}\right)$, intrinsic rate of increase $\left(r_{m}\right)$ and the finite rate of increase $(\lambda)$ were higher at $35^{\circ} \mathrm{C}$ than at $15^{\circ} \mathrm{C}$ and $25^{\circ} \mathrm{C}$.
\end{abstract}

Keywords: Stethorus gilvifrons (Mulsant), thermal requirements, biological characteristic, life table, Tetranychus urticae (Koch).

\section{INTRODUCTION}

Two spotted spider mite Tetranychus urticae (Koch).is one of the most polyphagous species of the Tetranychide attacking vegetables and fruit and several agricultural crops causing economic damage (Ripa et al, 2006). T.urticae is cousing to environmentale condition and distributed world wide, which causing a loss of the quiltyand loss yield or the death plants by sucking out the contents of plant scap (Rott et al 2000b).Maximum and minmum temperature thresholds and optimal temperature can be estimated for all life table (Roy, et al, 2001 and Roy., et al 2002). Factors wearther such as high and low temperature adversely affected of the population Stethours spp, (Kumar, et al 2010). They are maney of coccinellid such as, $S$. gilvifrons and S.Punctum picies are the effective natural enemies of the phytophagous mite, included T.urticae,T . piercei ,Gregor, et al 1986 and Gencer, et al 2005. They are Several studies were attention to the importance of this coccinellid species as the predator. Coccinellid predator could be play a good result for mass rearing and release in open fields and greenhouses, $S$. gilvifrons has a good search activity (Atlihan and Kaydan, 2002; El-Serafi, 2006 and Mohamed et al., 2008).

Life table parameters are helped to know the general biology of an predators and present a valuable picture for the fecundity and growth potential of $S$. gilvifrons under prevailing environmental conditions. Population growth rate is a basic ecological characteristic. It is usually expressed as the intrinsic rate of natural increase $\left(r_{m}\right)$ which is regarded as the best available single description of the population growth of species under given conditions (Shih et al. 1991). The intrinsic rate of natural increase $\left(r_{m}\right)$ can be used for predator's selection. Morever, $r_{m}$ is a suitable for evaluation of the mass rearing quality of biological control agents. It can be determined by its developmental time and reproduction rate. It has been used to compare a species under different environmental conditions and as an index of population rate response to selected preys (Birch,1948; Hulting et al.,1990; Roy et al., 2003; and Lanzoni et al 2004) ascanty attention has been paid to the rate of developmental time and growth index, longevity, fecundity and life table parameters of this predator to measure these parameters for mass rearing and release. This information to the present study was designed to study certain thermal requirements, biological characters and life table parameters of $S$. gilvifrons at three constant temperaturesand reared on T.urticae.

\section{MATERIALS AND METHODS}

Experiments were conducted at Plant Protection Research Institute, during one year 2016.The preadator adults of Stethous gilvifrons (Mulsant) were collected from the different fields at Mansoura district. The beetel reared on cowpea bean plants artificially infisted with Tetranychus urticae (Koch) mentonied for 2-3 week before testing The eggs laid by females were collected daily, and monitored until hatching,To avoid cannibalism, hatched larvae were reared individually in tubes $(10 \mathrm{~cm}$ in diameter) in the incubators at $15 \pm 0.5$, $25 \pm 0.5$ and $35 \pm 0.5^{\circ} \mathrm{C}$. The relative humidity was 70.0 $\pm 5.0 \%$ and the photoperiod was 18:6 (L: D) with each temperature. Tewenty replicates were carried out for each tested temperature of larval stage of of S. gilvifrons larvae from the predator were reared on T. urticae. Each reared larva was considered a replicates. Feeding on T.urticae leaf disc $(2.5 \mathrm{~cm})$ was artificially infisted with fifty of prey individuals. The cell was checked larvae calculatd. The predatory larva was transferred to new 
fresh number of the same prey. The procedure the experimental cell sepeated until the pupation larva of the predators. The stage adult of S.gilvifrons feeding on T.urticae leaf disc $(2.5 \mathrm{~cm})$ was artifiialliy infestedby preys individules. Each newly emerged predators adult was kept separately on the leaf disc in the experimental cells. The longevity of females was divided to three periods according to Phoofolo and Obrycki 1995 and Lanzoni et al. 2004. The pre-oviposition period was measured as the number of days among female eclosion and initiation of egg laying, the oviposition period was the number of days during which oviposition occurred. The fecundity of female, fecundity rate (number of progeny produced per female per day) and the post oviposition one as the numbers of days femaile don't laid the eggs. The longevity of males were recorded. The cells checked daily until the death of the predator dult. The developmental time and rate (1/developmental time) (Omakar and James, 2004) of immature stages, survival from eggs to adult eclosion, and sex ratio were recorded. The ability of the larvae to moult and metamorphose on the tested preys was determined as (a) percentage of individuals transforming into adults, and (b) average period required. The ratio of (a) to (b) then represented the insect's "growth index" (Saxena, 1969).

Campbell et al. (1974) . described the developmental times for eggs, larval instars, total larval stage, pupal stage and total immature stages were used to calculate the developmental rates, which were regressed against temperatures. The regression parameters and slopes were used to showed the lower temperature threshold for development $\left(\mathrm{t}_{\mathrm{o}}\right)$ and the thermal constant $\mathrm{K}$, as

life table parameters were calculated using a BASIC computer program (Abou-Setta et al. 1986) for females reared on T. urticae. This computer program is based on Birch's method (1948) for the calculation of an animal's life table. Constructing a life table, using rates of age-specific (Lx), and fecundity (Mx) for each age interval (x) was assessed. The following population growth parameters were determined: the mean generation time $(\mathrm{T})$, gross reproductive rate (GRR) $(=\Sigma \mathrm{Mx})$, the net reproductive increase $\left(R_{o}\right)$, the intrinsic rate of increase $\left(r_{m}\right)$, and the finite rate of increase $(\lambda)$. The doubling time (DT) was calculated according to Mackauer's method (Mackauer, 1983). The life tables were prepared from data recorded daily on developmental time (egg to first egg laid), sex ratio, the number of deposited eggs, the fraction of eggs reaching maturity, and the survival of females. Interval of one day was chosen as the age classes for constructing the life table.

Degree day requirements have been developed using a varity of non-linear functions that describe the temperature /growth rate relation ship (Wagner et al, 1984) ,but for most species the linear approximation is acceptable (Taylor and James, 1993).

\section{Data analysis:}

Data of developmental times of immature stages, consumption of larvae and adults, pre-oviposition, inter- oviposition, and oviposition periods, total longevity of females, fecundity, fecundity rate, and the males longevity of $S$. gilvifrons reared on $T$. urticae at three tested temperatures were subjected for one way analysis of variance (ANOVA), and the means were separated using Duncan's Multiple Range Test (CoHort Software, 2004).

The eggs Incubation period, larval stage were used to calculate developmental rates (1/developmental time) according to Omkar and James(2004), which were regressed against temperature.The regression parameters and slopes were used to estimate the lower temperature threshold for development $\left(\mathrm{T}_{\Theta}\right)$ and the thermal constant K, Campbell et al., (1974).

\section{RESULTS AND DISCUSSION}

\section{Developmental times of immature stages}

Statistical analysis of variance (ANOVA) of the experiments indicated that a high significant variations in the incubation periods for immature stages among the three tested temperatures $\left(15,25\right.$, and $\left.35^{\circ} \mathrm{C}\right)$ when the predator reared on T. Urticae (Table 1).

Data presented in Table (1) showed that the developmental time of the incupation period 7.4,3.6 and 2.2days. The four larval instars developmental time was $6.4,3.4,4.6$, and 6.2 days, respectively at $15^{\circ} \mathrm{C}$, while that was $3.8,2.6,2$, and 1.8 days at $25^{\circ} \mathrm{C}$, and $2.2,2$, 1.4 , and 1.8 days at $35^{\circ} \mathrm{C}$, with significant differences in $1^{\text {st }}, 2^{\text {nd }}, 3^{\text {rd }}$ and $4^{\text {th }}$ instar larvae when reared the predator on $T$. urticae as a prey among the three tested temperatures. The developmental time of larval stage was 20.6, 10, and 7.4 days, with significant differences among the three tested temperatures. The pupal stage averaged $6.4,5.2$, and 2.8 days at 15,25 , and $35^{\circ} \mathrm{C}$, with significant differences. The total developmental time of immature stages was $27,15.2$, and 10 days at 15, 25, and $35^{\circ} \mathrm{C}$, with significant differences.

Table 1. Developmental times (mean $\pm \mathrm{SE}$ and on LSD) in days of immature stages of $S$. gilvifrons when reared $T$. urticae at three constant temperatures.

\begin{tabular}{lcccc}
\hline Predator & \multicolumn{4}{c}{ Duration in days } \\
\cline { 2 - 5 } immature & $\mathbf{1 5}^{\circ} \mathbf{C}$ & $\mathbf{2 5}^{\circ} \mathbf{C}$ & $\mathbf{3 5}^{\circ} \mathbf{C}$ & $\mathbf{L S D}$ \\
\hline A:Egg incubation & $7.4 \pm 0.89 \mathrm{a}$ & $3.6 \pm 0.84 \mathrm{~b}$ & $2.2 \pm 0.45 \mathrm{c}$ & 0.712 \\
period & & & & \\
B: Larval stage: & $6.4 \pm 1.14 \mathrm{a}$ & $3.8 \pm 0.84 \mathrm{~b}$ & $2.2 \pm 0.45 \mathrm{~b}$ & 1.33 \\
$1^{\text {st }}$ instar & & & & \\
$2^{\text {nd }}$ instar & $3.4 \pm 0.54 \mathrm{a}$ & $2.6 \pm 0.55 \mathrm{ab}$ & $2 \pm 0.71 \mathrm{~b}$ & 0.912 \\
$3^{\text {rd }}$ instar & $4.6 \pm 0.54 \mathrm{a}$ & $2 \pm 0.70 \mathrm{~b}$ & $1.4 \pm 0.55 \mathrm{~b}$ & 0.834 \\
$4^{\text {th }}$ instar & $6.2 \pm 1.09 \mathrm{a}$ & $1.8 \pm 0.84 \mathrm{~b}$ & $1.8 \pm 0.84 \mathrm{~b}$ & 1.180 \\
Total larval stage $20.6 \pm 2.05 \mathrm{a}$ & $10 \pm 1.24 \mathrm{~b}$ & $7.4 \pm 3.02 \mathrm{c}$ & 0.982 \\
C:pupal & $6.4 \pm 0.55 \mathrm{a}$ & $5.2 \pm 0.84 \mathrm{~b}$ & $2.8 \pm 0.84 \mathrm{c}$ & 1.550 \\
D.Life cycle & $27.00 \pm 2.24 \mathrm{a}$ & $15.3 \pm 1.64 \mathrm{~b}$ & $10 \pm 1.87 \mathrm{~b}$ & 3.602 \\
\hline
\end{tabular}

Means followed by the same letter a column for each insect species are insignificantly different at the $5 \%$ level probability (Duncan's Multiple Range Test).

\section{Longevity and fecundity of adult stage:}

Longevity and fecundity of $S$. gilvifrons when reared on T. urticae at the three tested temperatures (15, 
25 , and $35^{\circ} \mathrm{C}$ presented in Table (2). T.urticae as a preoviposition, ovipositio, and post oviposition total longevity periods lasted $6,45.8,4.6$, and 55.2 days, respectively at $15^{\circ} \mathrm{C}$, while these periods lasted 2.6 , 39.4,5.2 and 46.2 days at $25^{\circ} \mathrm{C}$, and 2.2, 35.6, 4.8, and 42.6 days at $35^{\circ} \mathrm{C}$.Data presented a significant differences in pre-oviposition period on the three tested temperatures. In addition, there were significant variations among post oviposition, oviposition, and total longevity when the predator were reared at $35^{\circ} \mathrm{C}$ than at $15^{\circ} \mathrm{C}$ and $25^{\circ} \mathrm{C}(55.2,46.6$ and 42.6 days) which fed on the same prey. Concerning the fecundity of females eggs, the average number of eggs per female was 150.6 , 287 , and 373.5 at $\left(15,25\right.$ and $35{ }^{\circ} \mathrm{C}$ respetively with significant differences among the three tested temperatures (Table 2). Results in Table (2) showed that fecundity rate was significantly higher $(17.16)$ at $25^{\circ} \mathrm{C}$ than at $15^{\circ} \mathrm{C} \& 25^{\circ} \mathrm{C}(3.2$ and 6.16$)$, eggs per day when fed on the same prey.

Table 2. Longevity (mean \pm SEon $L S$ D ) in days of $S$. gilvifrons when reared of $T$. urticae at different temperature.

\begin{tabular}{|c|c|c|c|c|c|c|c|}
\hline \multirow{2}{*}{$\begin{array}{l}\text { Temp. } \\
\left({ }^{\circ} \mathrm{C}\right)\end{array}$} & \multirow{2}{*}{ Sex } & \multicolumn{4}{|c|}{ Longevity (in days) } & \multirow{2}{*}{$\begin{array}{c}\text { Mean total } \\
\text { fecundity }\end{array}$} & \multirow{2}{*}{$\begin{array}{l}\text { Fecundity rate (No. } \\
\text { eggs/Female/ day) }\end{array}$} \\
\hline & & Pre-oviposition & oviposition & Post-Oviposition & Total longevity & & \\
\hline \multirow{2}{*}{15} & ô & - & - & - & $61.3 \pm 2.28 \mathrm{a}$ & - & - \\
\hline & $q$ & $6 \pm 0.71 \mathrm{a}$ & $45.8 \pm 4.91 \mathrm{a}$ & $4.6 \pm 1.3 \mathrm{a}$ & $55.2 \pm 3.56 \mathrm{a}$ & $150.6 \pm 2.5 \mathrm{a}$ & $3.2 \pm 0.2 \mathrm{a}$ \\
\hline \multirow{2}{*}{25} & $\hat{0}$ & & - & - & $43 . \pm 7.38 \mathrm{~b}$ & - & - \\
\hline & q & $2.6 \pm 0.55 \mathrm{~b}$ & $39.4 \pm 2.97 \mathrm{~b}$ & $5.2 \pm 1.92 \mathrm{a}$ & $46.6 \pm 5.22 \mathrm{a}$ & $287 \pm 1.8 \mathrm{~b}$ & $7.3 \pm 2.8 \mathrm{~b}$ \\
\hline \multirow{2}{*}{35} & $\hat{o}$ & - & - & - & $34.3 \pm 6.39 \mathrm{c}$ & - & - \\
\hline & q & $2.2 \pm 0.48 \mathrm{~b}$ & $61 \pm 85 \mathrm{~b}$ & $4.8 \pm 2.59 \mathrm{a}$ & $42.6 \pm 4.15 b$ & $373.5 \pm 5.2 \mathrm{c}$ & $6.16 \pm 0.9 \mathrm{~b}$ \\
\hline \multirow{2}{*}{ LSD } & $\hat{0}$ & - & - & - & 7.39 & - & - \\
\hline & $q$ & 0.97 & 5.50 & 3.20 & 14.287 & - & - \\
\hline
\end{tabular}

Means followed by the same letter a column for each insect species are insignificantly different at the $5 \%$ level probability (Duncan's Multiple Range Test).

These result agree with Ahmed and Ahmed (1989)were studied the life history of the predator coccinellid S. gilvifrons using Tetranychus turkestani (Banks) as prey in laboratory at $20,25,30$ and $35^{\circ} \mathrm{C}$ and $65-75 \% \mathrm{RH}$. The average incubation period of the eggs was 2.9-5.3 days and the larvae and pupal period was 5.3-12.1 days and 2-5.6 days at 35 and $30^{\circ} \mathrm{C}$, respectively. The longest life span for male and female was 167.6 and 124.8 days, respectevily, at $20^{\circ} \mathrm{C}$ and 47.0 and 42.6 days at $35^{\circ} \mathrm{C}$, respectively.Mean while this studied agree with Shih et al. (1991) studied in the laboratory at $23.8 \pm 1.5^{\circ} \mathrm{C}$ and $70.84 \pm 4.3 \% \mathrm{RH}$, the coccinellid predator Stethorus loi Sasagi it completed the development within $15.27 \pm 1.46$ days. The durations of the egg, $1^{\text {st }}, 2^{\text {nd }}, 3^{\text {rd }}$, and $4^{\text {th }}$ instar larvae and pupal stages were $1.79 \pm 0.58,1.55 \pm 0.52,1.60 \pm 0.59,2.38 \pm$ 0.85 and $3.33 \pm 0.76$ days, respectively. The preoviopisitional and ovi-pisitional of stages were $4.14 \pm 1.75$ and $28.52 \pm 3.67$ eggs per day. Females and males lived for $48.38 \pm 15.46$ and $56.62 \pm 18.75$ days, respectively. The sex ratio was 1.063 males to one male where as in this study the sex ratioswas 0.45 . The intrinsic rate of natural increase was calculated to be 0.160 . The mean generation time was calculated to be 24.40 days by Iskander et al. (1994) estimated the development of $S$. punctillum in the laboratory on the phytophagous mite, Tetranychus arabicus Attiah, with the aim of studying development. Fecundity and feeding capacity of the former species when fed on the latter one at $25 \pm 1^{\circ}$ and $65 \pm 5 \% \mathrm{RH}$. The main durations of the egg, larval and pupal stages of $S$. punctillum were $3.67 \pm 0.49$, $6.67 \pm 0.62$ and $3.27 \pm 0.46$ days respectively. The life span was completed in $13.60 \pm 0.83$ days and longevity of adult female was $64.0 \pm 7.42$ days. Total number of eggs/female was 143.93 by daily number of 2.59 eggs. Mirdul et al. (2002) in India, studied the life history and feeding potential of $S$. gilvifrons a major predator of the spider mite, Oligonychus coffeae (Nietner). The beetle laid eggs singly on both surface of tea leaves and rear or in the middle of a mite colony. There were four instars grups, pupation occurred on both surfaces of the leaves and one end of the pupa was attached to the leaf surface or on the site of pupation. The authors noticed also that the male adults were smaller in body size than female. The predator completed its development in $16.33 \pm 1.13$ days. The duration of the egg, larval and pupal stages were $4.15 \pm 0.94,8.36 \pm 0.48$ and $3.82 \pm 0.94$ days, respectively, was studied in Iran under laboratory conditions at 30-34 deg $\mathrm{C}$ and $45-55 \% \mathrm{RH}$. A single generation took 14 days to develop from egg to egg. The adult females, of which the life-span averaged 62.4 days, laid an average of 394 eggs each during an oviposition period averaging 59.4 days; the hatching rate was about $98 \%$. Studies on the biology of this coccinellid under lath-house conditions in March-April at 22-26 deg. C and $40-50 \%$ RH gave results similar to those obtained in the laboratory. In the field, the number of females produced was double the number of males.Georgis et al.(1992). Reported that $34 \mathrm{deg} \mathrm{C}$ and $45-55 \%$ RH. A single generation took 14 days to develop from egg to egg. The adult females, of which the life-span averaged 62.4 days, laid an average of 394 eggs each during an oviposition period averaging 59.4 days; the hatching rate was about $98 \%$.

\section{Growth index (GI) and developmental rate (DR).}

Growth index of $S$. gilvifrons male was 2.15 , 4.25 , and 6.07 at the three tested temperatures $(15,25$, and $35{ }^{\circ} \mathrm{C}$, respectively) when reared on $T$. urticae 
(Table 3). Meanwhile for female, they were 2.20, 5.90, and 7.27 at the three tested temperatures.

Developmental rates of $S$. gilvifrons male and female were $0.022,0.023$, and 0.013 at the three tested temperatures $\left(15,25\right.$, and $35{ }^{\circ} \mathrm{C}$, respectively), when reared on $T$. urticae (Table 3). The female averged 0.18 , 0.023 and 0.023 respectively.

In general, GI and DR were better for $S$. gilvifrons adults (male and female) when reared on $T$. urticae at $35^{\circ} \mathrm{C}$ than at 15 and $25^{\circ} \mathrm{C}$. These result are similar with those Abdel-Salam et al . (2010).

Table 3. Growth index of male and female of $S$. gilvifrons reared on $T$. urticae at different temperatures.

\begin{tabular}{cccc}
\hline Sex & Temp. $\left({ }^{\mathbf{0}} \mathbf{C}\right)$ & Growth index & Developmental rate \\
\hline \multirow{4}{*}{} & 15 & 2.15 & 0.022 \\
& 25 & 4.25 & 0.023 \\
& 35 & 6.07 & 0.013 \\
& 15 & 2.20 & 0.018 \\
+ & 25 & 5.90 & 0.023 \\
\hline
\end{tabular}

\section{Life table parameters}

Results in Table (4) indicated that $S$. gilvifrons females life table parameters when reared on T. urticae at the three tested temperatures 15,25 , and $35^{\circ} \mathrm{C}$ ).
The mean generation time (T) was 40.66, 28.76, and 20.23 days at 15,25 , and $35^{\circ} \mathrm{C}$, respectively when reared on $T$. urticae. The population of this predator could be doubled every $0.15,8.84$, and 6.15 days at 15 , 25 , and $35^{\circ} \mathrm{C}$, respectively when reared on T. urticae. The value of gross reproductive rate (GRR) was higher (148.39) at $35^{\circ} \mathrm{C}$ than at $15^{\circ} \mathrm{C}$ and $25{ }^{\circ} \mathrm{C}(69.48$ and 122.67). GRR refers to the sum of the average number of females produced per living female per day. This value is greater than the simple mean estimate of total fecundity per female per generation. The net reproduction rat $\left(R_{o}\right)$, representing the total female births was 105.95 at $35^{\circ} \mathrm{C}$. This meant that the population of this predator would be able to multiply 105.95 times when fed on $T$. urticae at the end of each generation. $R_{o}$ was 48.76 at $15^{\circ} \mathrm{C}$ and 97.52 at $25^{\circ} \mathrm{C}$. The value of the intrinsic rate of increase $\left(r_{m}\right)$ was $9.56, .16$, and 0.23 when the predator was reared on $T$. urticae at the three tested temperatures $\left(15,25\right.$, and $\left.35^{\circ} \mathrm{C}\right)$. The finite rate of increase $(\lambda)$ was $1.1,1.17$, and 1.35 at the three tested temperatures $\left(15,25\right.$ and $\left.35^{\circ} \mathrm{C}\right)$ that the population had the capacity to multiply $1.1,1.17$ and 1.35 times per female per day.

Table 4. Life table parameters of S.gilivfrons females when reared on $T$. urticae at different temperatures

\begin{tabular}{lcccccc}
\hline $\begin{array}{l}\text { Temp. } \\
\left({ }^{\circ} \mathbf{C}\right)\end{array}$ & $\begin{array}{c}\text { Mean generation } \\
\text { time (T) (in days) }\end{array}$ & $\begin{array}{c}\text { Doubling time } \\
\text { (DT) (in days) }\end{array}$ & $\begin{array}{c}\text { Gross reproductive Net reproductive Intrinsic rate of } \\
\text { rate (GRR) }\end{array}$ & $\begin{array}{c}\text { Finite rate of } \\
\text { rate }\left(\mathbf{R}_{\mathbf{0}}\right)\end{array}$ & $\begin{array}{c}\text { increase }\left(\mathbf{r}_{\mathbf{m}} \text { ) }\right. \\
\text { increase }(\boldsymbol{\lambda})\end{array}$ \\
\hline 15 & 40.66 & 0.15 & 69.48 & 48.76 & 9.56 & 1.1 \\
25 & 28.76 & 8.84 & 122.67 & 97.52 & 0.16 & 1.17 \\
35 & 20.23 & 6.15 & 148.39 & 105.95 & 0.23 & 1.35 \\
\hline
\end{tabular}

\section{Degree-Day Requirements}

Sharpe and De Michele (1977), studied the relationship between temperature and rate of development in insects and mites is usually calculated as linear, but it is actually curvilinear.

Minimum developmental thresholds $\left(\mathrm{T}_{\mathrm{o}}\right)$ of egg, larvl stages, pupa and life cycle of $S$. gilvifrons immature stages were recorded as $7.4,4.53$, Whereas, S.gilivifrons required 410.59 DD to complete their development from egg stage to adult when reared on $T$. urticae (Table 5 \& Figs. 1). Using the linear model, the estimated low temperature threshold for egg, larva, $1^{\text {st }}$ $, 2^{\text {nd }}, 3^{\text {rd }} 4^{\text {th }}$, pupa, and life cycle immature stage of $S$. gilvifrons was $7.6,4.53,13.56,6.78,0.57$ and 7.86 degrees $\mathrm{C}$, respectively while the thermal constant for these stages was 733.10, 695.72, 1059.37, $369.42,640.62$ and 410.59 degree-days, respectively.

Table 5. Linear regression analysis of temperature versus developmental rate, degree-days requirements, and minimum developmental thresholds of S.gilivrons (Muls) female reared on T. urticae .

\begin{tabular}{|c|c|c|c|c|c|}
\hline Predator & Stages & Regression & $\mathbf{R}^{2}$ & K(DD) & $\mathbf{T}_{0}$ \\
\hline \multirow{5}{*}{ 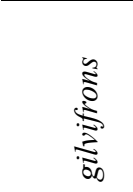 } & Egg & $Y=-9.591+1.825 x$ & 0.858 & 733.10 & 7.6 \\
\hline & $1^{\text {st }}$ instar & $Y=-8.157+1.491 x$ & 0.974 & 695.72 & 4.53 \\
\hline & $2^{\text {nd }}$ instar & $\mathrm{Y}=13.55+1.029 \mathrm{x}$ & 0.995 & 518.11 & 13.56 \\
\hline & $3^{\text {rd }}$ instar & $Y=-14.45+2.486 x$ & 0.993 & 1059.37 & 6.27 \\
\hline & $4^{\text {th }}$ instar & $\mathrm{Y}=1.576+2.486 \mathrm{x}$ & 0.621 & 369.42 & 6.78 \\
\hline \multirow[t]{2}{*}{$\dot{4}$} & pupa & $Y=-0.0139+0.0048 x$ & 0.879 & 640.62 & 0.57 \\
\hline & Life cycle & $Y=-1.115+0.315 X$ & 0.997 & 410.59 & 7.86 \\
\hline
\end{tabular}

The present findings were similar to the data by Taghizadeh, et al. (2008) who fined the total development time at temperatures tested was 56.47, $31.19,18.53,17.54,12.49$, and 9.27days, respectively, which recorded a significant decrease of development time with increasing temperature. under laboratory conditions at $15,20,25,28,30,35$ and 40 degrees $\mathrm{C}^{\mathrm{O}}$ and recorded no development occurred at 40 degrees $\mathrm{C}^{\mathrm{O}}$. 

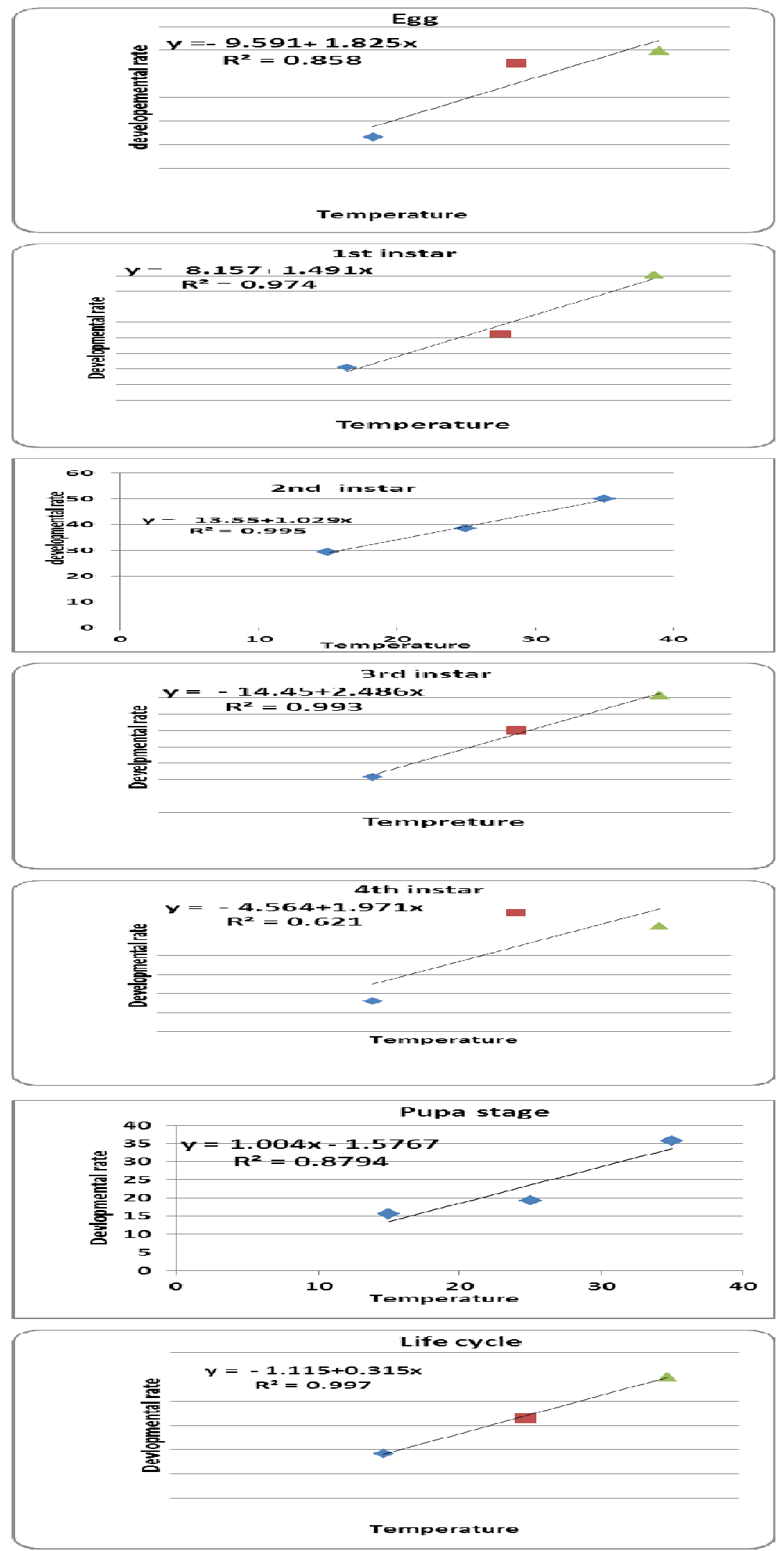

Figure 1. Linear regression analysis of temperature versus developmental rate, degree - days requirements, and minimum developmental thresholds of S.gilvifrons (Mulsant) immature stage reared on $T$. urticae (Koch) 
Peterson et al. (1994) in New Zealand, recorded the development of the coccinellid Stethorus bifidus Kapur at $65.80 \%$ RH , LD 6.8 and 8.5 , 12.5, 17.0, 21.0, 24.5 and $27.5^{\circ} \mathrm{C}$ using Tetranychus lintearius (Dufour) as a prey they found that the relationship between temperature and development rate was linear between 12.5 and $27.5^{\circ} \mathrm{C}$ for eggs, $4^{\text {th }}$ larval instars and pupae development thresholds ranged from $9.4^{\circ} \mathrm{C}$ for $3^{\text {rd }}$ instar larvae to $11.9^{\circ} \mathrm{C}$ for eggs, development from egg to adult lasted 217 days.

Mass production of coccinellid predators in biological control programs requires huge numbers at low costs. It is desirable to choose the predator, which has short developmental times and a high reproductive capacity.

In conclusion, $S$. gilvifrons had a shorter developmental time of immature stages, a relatively higher survivorship, a moderately longevity, a higher fecundity, and a higher intrinsic rate of natural increase $\left(r_{m}\right)$. Therefore, it has a fine potential for mass rearing and periodic release. This predator presents excellent opportunity of a biological control agent that could be monitored and manipulated in an integrated pest management (IPM).This information may be used as an important mean in planning successful integrated pest management (IPM) program for this spider mite.

\section{REFERENCES}

Abdel-Salam, A. H.; Ghanim, A. A.; El-Serafi, H. A. K.; El-Naggar, M. E. and Saleh, F. M. 2010. Biological life table parameters of Stethours gilvifrons (Muls.) (Coleoptera: Coccinellidae) Reared on Tetranychus.urticae Koch. J, plant protection, Mans Univ., vol.1(6) ; 393 - 402

Abou-Setta, M. M.; Sorrell, R. W. and Childers, C. C. 1986. Life 48: A BASIC computer program to calculate life table parameters for an insect or mite species. Fla. Entomol. 69: 690-697.

Ahmed, Z . L . and R .F. Ahmed 1989 . Biological studies Stathorus gilvifrons Mulsant (Coleoptera : Coccinellidae) on the strawberry mite, Tetranychus turkestani ugarov and Nikolski (Acariformes: J. Bio L. Sci Research, 20 (1) : 22 -33 .

Atlihan, R. and Kaydan, M. B. 2002. Development, survival, and reproduction of three coccinellids feeding on Hyalopterus pruni (Geoffer) (Homoptera: Aphididae).Turk. J. Agric. For. 26: 119-124.

Birch, L. C. 1948. The intrinsic rate of natural increase of an insect population. J.Anim.Ecol., 17: 15 26.

Campbell, A.,B. Frazer, N. Gilbert, A. Guitierrez, and M. Mackauer. 1974. Temperature requirements of some aphids and their parasites. J. Appl. Ecol. 11: 431-438.
CoHort CoStat Software 2004. www.cohort.com. Monterey, California, USA.

El-Serafi, H. A. K. 2006. Biological characteristics of the coccinillid predator Exochomus nigromactilatus (Goeze) reared on certain aphid species under laboratory conditions. J. Agric. Sci. Mansoura Univ., 31 (2): 1033 -1043.

Gencer, N, S,Coskuns K, S and ,Kumral N, A. 2005.Determination of harmful and beneficial fauna in fig orchards in Bursa Province Ondokuz mays Universitesi,Ziraat Fakultesi Dergisi,(2)2430.

Georgis, R.; Wahab, W. A.; and El-Haidari , H. S. 1992. Observation on biology of Stethorus gilvifrons Muls., a predator of Tetranychus atlanticus McG. [Arabic] Yearbook of Plant Protection Research, Iraq Ministry of Agriculture and Agrarian Reform; 1974/1976, recd. 1978. 1: Ar pp. 47-50

Hulting, F. L.; Orr, D. B. and Obrycki, J. J. 1990. A computer program for calculation and statistical comparison of intrinsic rates of increase and associated life table parameters. Fla. Entomol. 73: 601-612.

Iskander, N.G.; R.A. Sedrak and S.M. Ibrahim 1994. Studies on development, Fecundity and predation efficiency of Stethorus punctillum weise (Coccinellidae : Coleopteran) on the red spider mite. Tetranychus arabucus Egypt. J. Appl. Sci., 9 (8) : 330-338.

Kumar G ,Karthik . L and Bhaskara Rao. K.V.2010.Antibacterial activity of aqueous exteract of Caloropis gigantean leaves -an in vitro study.Int.J pharma sci review and Research.;(2):141-144.

Lanzoni, A .; Accinelli , G.; Bazzocchi, G. G. and Burgio, G. 2004. Biological traits and life table of the exotic, Harmonia axyridis compared with Hippodamia variegata and Adalia bipunctata (Col., Coccinellidae). J. Appl. Ent. 128: 298-306.

Lui Z , and Lui N .Z. 1986. A Preliminary repot on Tetanychus pierces McGregor, Insect Knowledge (1);18-19.

Mackaure, M. 1983. Quantitive assessment of Aphidius smith (Hymenoptera:Aphididae) . Fecundity, intrinsic rate of increase, and Functional response.Can .Entomol.,115:399-415.

Mirdul, S.; B. Bhattacharyya; M. Sarmah and B. Bhattacharyya 2002. Biology and Feeding potential of Stethorus gilvifrons Mulsant (Coccinellidae : Coleoptera) on tea red spider mite, Oligonychus coffeae Neitner. Shashapa, 9 (1) :23-26.

Mohamed, N. E.; Ghanim, A. A. and Abdel-Salam, A. H. 2008. Biological parameters of the two coccinellid predators, Exochomus nigromaculatus (Goeze) and Hippodamia convergens Geur. reared on certain aphid species under controlled conditions. J. Agric. Sci., Mansoura Univ., 33(10):7509-7517. 
Omakar and James, B. E. 2004. Influence of prey species on immature survival, development, predation, and reproduction of Coccinella transversalis Fabricius (Col., Coccinellidae). J. Appl. Ent. 128: 150-157.

Peterson, P.G.; P.G. McGregor; B.P. Spri-ngett and A. popay 1994. Development of Stethorus bifidus in relation to temperature : implication for regulation of gorse spider mite population. Proc. 4th New Zealand plant protection conf., Waitangi Htel New Zealand : 103-106.

Phoofolo, M. W. and Obrycki, J. J. 1995. Comparative life history studies of nearctic and palearctic populations of Coccinella septempunctata (Coleoptera: Coccinellidae). Environ. Entomol . 24: 581-587.

Ripa.SR, Rodriguez AF, Larral. D P and Luck RF; 2006. Evaluation of a detergent based on sodium benzene sulfonate for the control of wooly whitefly Aleurothrixus floccosus (Maskell) (mcGregor) (Acarina; Tetranychidae) on oranges and mandaris Agriculture Tecnic,66(2)115-123.

Rott A S , Ponson by D J 2000 stb.The effects of temperature relative humidityand host plant on the behavior of Stethours puncillumasa predator of the-spotted spider mite ,Tetrnychus urticae.Biocontrol;45:155-164.

Roy M,Brodeur ;ABrodeur J,Cloutier C. 2002.Relationship between temperature and developmental rate of Stethours punctillum (coleopteran;Coccinellidae)and its prey tetranychus mcdanieli (acarina;tetranychidae) .Environ. Entomol,31;177-187.

Roy M,Brodeur ; Brodeur J and Cloutier C. 2001.Evalution of the Effect of Two Treatment Approaches for teachers with voice Disorders;aProspective Randomize Clinical Trial. Environ .Entomol, 31 ; 287-296.
Roy, M.; Brodeur, J. and Cloutier C. 2003. Effect of temperature on intrinsic rates of natural increase $\left(\mathrm{r}_{\mathrm{m}}\right)$ of a coccinellid and its spider mite prey. Bio. Control 48: 57-72.

Saxena, K. N. 1969. Patterns of insect-plant relationships determining susceptibility or resistance of different plants to an insect. Eat. Exp. and Appl. 12: 751-766.

Shao, J. and Jin, W. 1987. Study on effective thermal constant temperature of Exochomus mongol (Borousky). J. North. East Forestry Univ. 15 (3): $35-42$.

Sharpe, J. H. and De Michele, D. W. 1977. Reaction kinetics of poikilotherm development. J. Theor. Biol. 64: 649 - 670 .

Shih, C.T.; P.J. Lin and T. Chang 1991. Biology, Predation, Life table and intrinsic rate of increase of Stathorus loi Sasaj plant protection Bulletin Taipei, 33 (3): 290-300.

Taghizadeh, R.; Fathipour, Y.; Kamali, K. 2008. Temperature-dependent develop pment of Acarophagous ladybird, Stethorus gilvifrons (Mulsant) (Coleoptera: Coccinellidae). J. of Asia-Pacific Entomology; 11(3):145-148.

Taylor, Ann and James, D. G. 1993. Effect of temperature on development and survival of Amblyseius victoriensis (Womersley) (Acari: Phytoseiidae). Internat. J. Acarol. Vol. 18, No.2

Wagner, T. L., H. Wu, P. J.H. Sharpe, R . M and Schofield, R.N. 1984. Modelling insect development rates: A literature review and application of biophysical model. Ann. Ent. Soc. Am. 77: 208 - 225.

\section{جداول الحياه و الإحتياجات الحرارية و معدلات النمو للمفترس

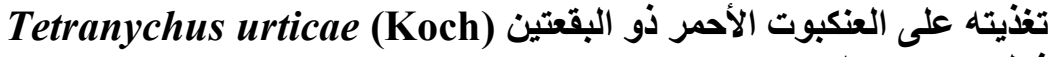 فاطمه محمد صالح معهد بحوث وقاية النباتات ـ مركز البحوث الزراعية - وزارة الزراعه.}

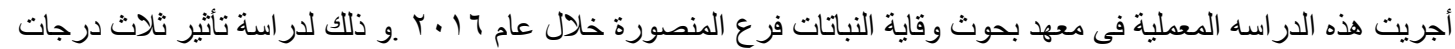

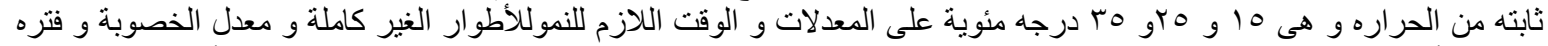

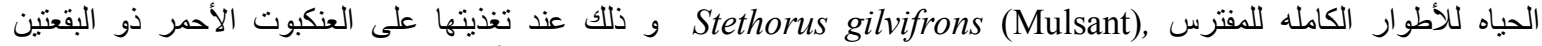
Tetranychus urticae Koch

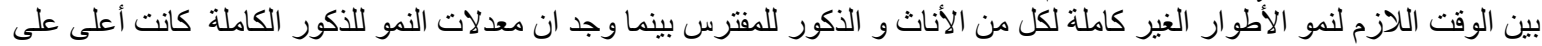

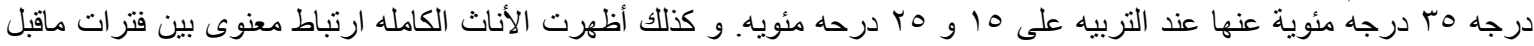

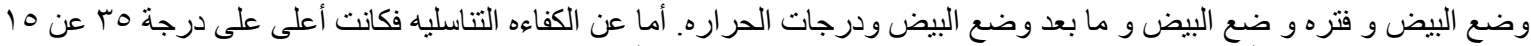

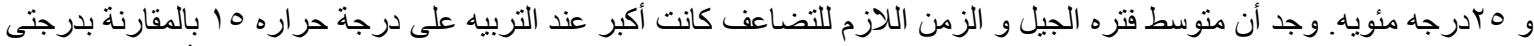

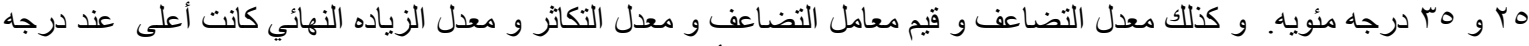

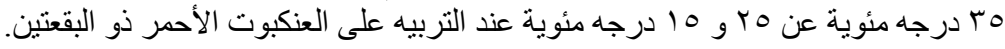

